\title{
A RELATION BETWEEN PASSENGER CAR BRAND IMAGE AND CONSUMER LOYALTY. A PROOF BASED ON CLUSTER ANALYSIS
}

\author{
Aleksander LOTKO $^{1 *}$, Radosław LUFT ${ }^{2}$ \\ ${ }^{1}$ University of Technology and Humanities, Faculty of Economic and Legal Sciences, Poland; \\ aleksander.lotko@uthrad.pl, ORCID: 0000-0003-4420-7495 \\ ${ }^{2}$ University of Technology and Humanities, Faculty of Economic and Legal Sciences, Poland; r.luft@uthrad.pl, \\ ORCID: 0000-0003-3361-6613 \\ * Correspondence author
}

Purpose: The purpose of this paper was to identify the relation between passenger car brand image and consumer loyalty.

Design/methodology/approach: A quantitative approach was used, and a questionnaire-based research was carried out. As a method of elaborating the results, cluster analysis was selected. Findings: It was discovered that the consumers from 2 clusters are significantly different both in terms of perception of car brand image and loyalty. In this way the existence of the assumed relation was proved.

Practical implications: A practical implication of the study is claiming the role of brand image in shaping consumer loyalty in the passenger cars market.

Originality/value: Authors' contribution and novelty of the paper is the innovative application of the multidimensional exploratory techniques of cluster analysis in the area of research. In management practice, the paper can turn out useful to marketing managers in the automotive industry.

Keywords: brand image, customer loyalty, automotive market, cluster analysis.

Category of the paper: research paper.

\section{Introduction}

A brand is "the entire marketing communication in a nutshell" (Kotler, 2006). It includes a message, connotations, emotions and it carries a number of values (Liczmańska, 2008). The image of a brand is also an abstract term. It covers a set of features and imaginations ascribed to a given brand that functions in the consumer's consciousness. A positive and at the same time unique brand image constitutes a capital necessary for keeping a high position in the competitive market. Moreover, it distinguishes a company from the competitors (TNS OBOP, 2011). 
While loyalty of the consumers is today perceived as the key determinant of the success of an organization in the market (Reichheld, and Sasser, 1990; Lam, and Burton, 2006; Eakuru, and Mat, 2008; Małysa-Kaleta, 2016), N. Eakuru and N. Mat (2008) argue that establishing new relations with consumers with the aim of improving their loyalty should be of the highest priority. Other authors (Lam, and Burton, 2006) suggest that loyal consumers significantly contribute to the increase of the share of an enterprise in the market. F. Reichheld and W. Sasser (1990) have demonstrated that an increase of the loyalty of the consumers by $5 \%$ may lead to the increase of the profit by around $20-25 \%$. This thesis is also confirmed by Y. Du and Y. Tang (2014).

In literature, the existence of relations between the brand and the loyalty of the consumers has been made evident many times (among others, by Selnes, 1993; Kressmann and others, 2006; Anisimova, 2007; Chi, and others, 2009). Here, the authors attempted to confirm it in the passenger car market in Poland. The purpose of the study was to identify the relation of the brand image of a passenger car with the loyalty of the consumers and to reveal the segmentation of the consumers. The following working theses have been posed:

$\mathrm{H}_{1}$ : In the passenger car market, the loyalty of the consumers is connected with the way they perceive the image of the brand and this relation has a positive character.

$\mathrm{H}_{1}$ : In the passenger car market, the consumers are creating groups (segments) which are homogenous in respect of the way the brand image and loyalty towards the brand is perceived.

Innovative application of the multidimensional exploratory techniques of cluster analysis has been used as the method of the verification of the above hypothesis and the achievement of the purpose of the study.

\section{The essence and the meaning of the brand image}

In the 80 's of the twentieth century, the brand was still presented as the name, term, sign, symbol, picture or combination of these elements created in order to mark the product and distinguish it from the competitive products (Kotler and Armstrong, 1989). However, the definition of the brand presented later by $\mathrm{Ph}$. Kotler ascribes greater meaning to it. The brand is not just 'a sign', symbolic logotype, but above all it is the affirmation, the promise that should shape the behaviour and the strategy of actions taken by an enterprise (Kall, 2002, 2006). The brand is, above all, the synonym of the quality, durability and the guarantee of the product (Remer, 2004). Modern marketing is of "post-material" character. The consumers buy brands and meanings which are read subjectively and they use cultural interpretations. Marketing communication takes place in the symbolic world. The increase of the role of the brand is one of the symptoms of this phenomenon (Sułkowski, 2012). 
In the literature of the subject, two important terms are particularly strongly connected with the brand image: identity and image. According to one definition, the brand is a multidimensional construction which integrates both physical and intangible attributes of the product and it is composed of three basic elements (Dębski, 2009):

1. The image of the brand i.e. the manner the consumers perceive the brand.

2. The identity of the brand i.e. the manner in which the brand creator wants it to be perceived by the consumers.

3. The positioning of the brand i.e. the demanded place of the brand in the market.

In symbolic, post-material sense, the brand is the perceived image present in the minds of the consumers (Dębski, 2009). Herein, the consumer creates the image of the brand in his mind on the basis of the experiences with it. The brand image is thus the basis of a number of further behaviours of the consumer in the market. It is worth noticing that the image of the brand is a derivative of its identity and it does not have to be the same.

It has been demonstrated that the brand image influences the cognitive aspect of consumer's attitude towards new products in the market marked with its sign (Grzegorczyk, 2005). In the emotional sphere (affective), the established brand image intensifies the feeling of satisfaction of the consumer from the purchase and the use of the product. In the loyalty sphere, the brand image is the guarantee of maintaining the quality (guarantee function) and functional attributes of the previously purchased product. The set of established gathered experiences of the use, conditions and emotions which simplify the decision-making process on the side of the consumer are important in terms of the preferences. The consumers with strongly rooted brand image are much more resistant to the promotional activities of competitive brands and in the case of being prone to them, they present a tendency of a relatively fast return to loyal behaviours (Grzegorczyk, 2005).

\section{The meaning of the loyalty of the customers}

The loyalty of the customers is perceived as the key determinant of the success of an organization in the market and one of the most important challenges of management (Lam, and Burton, 2006; Eakuru, and Mat, 2008; Reichheld, and Schefter, 2000). Additionally, the functioning in the Internet environment brings a lot of uncertainty for the enterprises connected with the loyalty of the customers. Easy access to information, reliance on the opinions of the users placed in the Internet, possibility of immediate comparison of prices and characteristics of the products and services evoke low loyalty of the customers and its increase is indispensable (Reichheld, and Schefter, 2000; Floh, and Treiblmeier, 2006). In the virtual environment, the problem of the loyalty of the customers has a particular meaning, because they are better informed, they have bigger choice, they have the possibility to directly compare 
the offers and thus exert stronger control over the sales process, and in the Internet, competition is just "one click away" (Cheng, and Zhang, 2015).

There are many ways of perceiving loyalty. The loyalty understood from the behavioural perspective is today substituted by the loyalty understood as posture or customer's attitude, which determines the behaviour (Oliver, 1997). Hence, of importance is not only customer's behaviour, but also motivation which triggers this behaviour. This approach has been introduced in order to distinguish the customers who are loyal only because of duress, inertia or lack of any alternative.

Researchers (Allen, and Rao, 2000) define two basic kinds of loyalty. These are:

1. Cognitive loyalty concerning preferences and objective assessment of an offer, as well as compliance of the brand image with the value-system of the customer. On the basis of the trust to a given brand and its attributes (such as the price, customer service), the customer prefers this brand to the other. As a rule, he makes the decisions on the basis of indirect information or his previous experience. This kind of loyalty is rather superficial.

2. Affective loyalty connected with the feelings, affections, mood and emotional engagement, attraction. This is a stronger form of loyalty, which is more difficult to be broken - as at this level it engages the feelings and preferences of the customer.

Oliver (1999) and Banahene, Ahudey and Asamoah (2017), based on K. Dick and A. Basu (1994), add two more loyalty phases:

1. Conative loyalty i.e. intentional loyalty resulting from a deep confidence and the striving for a repeated purchase. A customer attracted by a given company's offer many times over becomes sure that it is worth staying with that company's products, and he demonstrates his attachment by the will of repeated purchase (however, it is not always supported by actions).

2. Action loyalty, active, real loyalty covering conscious overcoming of difficulties in order to repeat the purchase. This is a loyalty that changes the motivation from the previous phase into the readiness to act. The customer is much more prone to overcome difficulties, which may occur, for example, due to the activities taken up by the competition aiming to take over the customer.

Hence, it could be said that loyalty is a multi-faceted and multidimensional construct and such an assumption was made in this empirical study. 


\section{The State of the Art in the Literature}

The identification of the relations between the brand image and the loyalty of the consumers is particularly important. That this issue was discussed in literature is made evident by searching Google Scholar base for the conjunction of the following phrases: brand image, consumer loyalty, automotive. After the analysis of the first three pages, it was discovered that the researchers have already analysed the following issues:

- Influence of the features of a given product on the brand reputation, as well as satisfaction and loyalty of the consumers (Selnes, 1993).

- Relation of brand reputation and trust in it with its market success (Herbig, and Milewicz, 1995).

- Trust in the brand in the context of the loyalty of the consumers (Delgado-Ballester, and Munuera-Aleman, 2001; Lau, and Lee, 1999).

- The role of loyalty towards the brand and the dependencies chain between the trust in the brand, affective attitude towards the brand and its perception (Chaudhuri, and Holbrook, 2001).

- Indirect and direct effects of the brand image for the loyalty of the consumers towards the brand (Kressmann, and others, 2006).

- Influence exerted by the corporate brand on the motivation and behavioural loyalty of the consumers in the passenger car market (Anisimova, 2007).

- Influence of the brand awareness on the intent of the next purchase - with consideration of mediation effects of the perceived quality and loyalty (Chi, and others, 2009).

- Consumers' perception of long-tradition brands in the automotive industry (Wiedmann, and others, 2011).

- Influence of informal message of whispered marketing in electronic networks on the brand image and intents of repeated purchase in the automotive industry (Jalilvand, and Samiei, 2012).

- Mediation model of dependencies between the quality of the management of relations with consumer and brand image (Nyadzayo, and Khajehzadeh, 2016).

- dimensionality of perception of automotive brands (Gabor, 2016).

- shaping the brand image in the Polish automotive market among children (Woźniakowski, 2018).

Thus, the considered issues are important. For example, T. Anisimova (2007) is the author of a work that discusses similar subjects. In this, she identifies factors at the level of a corporation and demonstrates that marketing activities having impact on the motivation and behavioural loyalty of consumers in the considered market. Moreover, M. Gabor (2016) applied G. Kelly's cognitive psychology of personality and the theory of cognitive constructing, in the study of the perception of automotive brands and segmentation of consumers. In this study, we tried to present a slightly different approach by combining image features of 
the brand directly with the loyalty of consumers. Furthermore, with the use of an electronic query, we simultaneously demonstrated that there are only a few available publications in the area of automotive brands. This results in a research gap. With this paper we attempted to fill this gap.

\section{Remarks on the Method}

In order to achieve the purpose of the study, we adopted the quantitative attitude. In Table 1 we present the procedure of preparing and conducting the empirical study.

Table 1.

Procedure of preparing and conducting empirical study

\begin{tabular}{|c|l|l|}
\hline No. & \multicolumn{1}{|c|}{ Task } & \multicolumn{1}{|c|}{ Methods of realization } \\
\hline 1. & Selection of the research subject. & Literature analysis, electronic query (Google Scholar). \\
\hline 2. & $\begin{array}{l}\text { Selection of variables used in the } \\
\text { measurement of the brand image and loyalty } \\
\text { of the consumers. }\end{array}$ & Electronic query (Google Scholar). \\
\hline 3. & Conduct of the empirical study. & Survey, questionnaire delivered personally. \\
\hline 4. & Verification of dependencies. & $\begin{array}{l}\text { Cluster analysis (agglomeration, Ward algorithm, } \\
\text { k-averages method). }\end{array}$ \\
\hline
\end{tabular}

Source: author's own study.

The empirical study was carried out with the use of a survey. Two hundred persons from Radom sub-region participated in the study. The study was carried out in January 2019. The values of the variables representing the brand image, as well as the loyalty of the consumers were both registered on a seven point Likert scale. Collected data was processed statistically with the use of Statistica 8.0 software.

Cluster analysis was used. This method was introduced by R. Tryon (1939). It is also specified as segmentation or data clustering. The use of the method of cluster analysis has significantly increased in the recent years (Stevens, 2009). It covers a couple of different algorithms and methods are applied to establish the grouping of similar objects in similar categories (StatSoft, 1997). Cluster analysis is an exploratory non-directed method. This means that all relations and regularities are explored on the basis of input variables. A characteristic fact is that contrary to numerous statistical procedures, the method of cluster analysis is often used in the exploratory phase of the study, i.e. when the researcher does not assume any of the theses a priori. This method in its nature reveals the structure of the studied set of objects.

Technically popular methods used in the cluster analysis are (StatSoft, 1997):

1. Agglomeration method (hierarchic tree).

2. Method of grouping the objects and features.

3. K-means method.

4. EM method (expectation maximization). 
We distinguish two types of algorithms that serve the creation of clusters: hierarchic and non-hierarchic algorithms. Hierarchic methods lead to obtaining a tree structure of the elements of the analysed set. The results of the carried out analysis are presented as a tree that demonstrates the next steps of the algorithm's activity. Various algorithms are used here. They do not require any earlier assumptions regarding the number of obtained clusters. The most popular method among hierarchic methods is the agglomeration method. Disadvantages of this group of methods include the fact that for big sets of data, a specified computing power is necessary in case of hierarchic algorithms. In contrast, non-hierarchic methods compute faster, however, they require declaration of previously assumed number of clusters - which significantly influences the obtained segmentation. Here, the k-averages method is popular (Stevens, 2009). When processing the results of the study, for the identification of the number of clusters, we at first applied the agglomeration method (Ward algorithm) and next the k-averages method. The last was applied in the analysis of the structure of discovered clusters, while segmentation was conducted on the basis of the analysis of cases (records).

The selection of attributes specifying the perception of the brand image of automotive brands was made on the basis of the analysis of the frequency they occur in: reports concerning the brand image of automotive brands (TNS OBOP, 2011; Consumer Reports, 2012; NRC, 2014) and scientific publications in this area (Gabor, 2016; Delgado-Ballester, and MunueraAleman, 2001). Thirty-two observable variables, listed in Table 2 were considered.

Table 2.

Variables characterizing the brand image used in the empirical study

\begin{tabular}{|c|l|c|l|}
\hline $\begin{array}{c}\text { Variable } \\
\text { marking }\end{array}$ & \multicolumn{1}{|c|}{ Variable name } & $\begin{array}{c}\text { Variable marking } \\
\text { (continued) }\end{array}$ & \multicolumn{1}{|c|}{ Variable name (continued) } \\
\hline W1 & Innovative & W17 & Futuristic \\
\hline W2 & Dynamic & W18 & Classic \\
\hline W3 & Prestigious & W19 & Available \\
\hline W4 & Environmentally friendly & W21 & Popular \\
\hline W5 & Reliable & W22 & Of high quality \\
\hline W6 & Extravagant & W23 & Catchy \\
\hline W7 & Practical & W24 & Universal \\
\hline W8 & Sporting & W25 & Moneysaving \\
\hline W9 & Cheap in exploitation & W26 & Functional \\
\hline W10 & Worth its price & W27 & With well-preserved value \\
\hline W11 & Dependable & W28 & Cheap \\
\hline W12 & Safe & W29 & Modern \\
\hline W13 & Feminine & W30 & Exciting \\
\hline W14 & Luxurious & W31 & Boosting confidence \\
\hline W15 & With long tradition & Family \\
\hline W16 & Comfortable & \\
\hline
\end{tabular}

Source: author's own study.

The study also included 4 variables representing previously mentioned types of loyalty applied by many contemporary researchers (Banahene, Ahudey, and Asamoah, 2017; Lotko, 2018). It should be added that according to the global trends (Morchett, Swoboda, and Foscht, 
2005; Robinson, and Gammon, 2004; Hibbert, Hogg, and Quinn, 2005), declarative motivation loyalty was measured, instead of behavioural loyalty. The indicators of motivation loyalty of the consumers are presented in Table 3.

Table 3.

Variables characterizing the loyalty towards the brand applied in the empirical study

\begin{tabular}{|c|l|}
\hline Variable marking & \multicolumn{1}{c|}{ Variable description } \\
\hline $\mathrm{L} 1_{\text {kogn }}$ & I think that the brand of my car is simply good. \\
\hline $\mathrm{L} 2_{\text {afekt }}$ & I really like the brand of my car. \\
\hline $\mathrm{L} 3_{\text {kon }}$ & I am planning to buy the next car of this brand. \\
\hline $\mathrm{L} 4_{\text {akt }}$ & I share positive opinions about the brand of my car among my friends. \\
\hline
\end{tabular}

Source: author's own study.

\section{The analysis and discussion of the results}

During the analysis of data obtained in the empirical study, we at first analysed the scatter diagram presented in Figure 1.

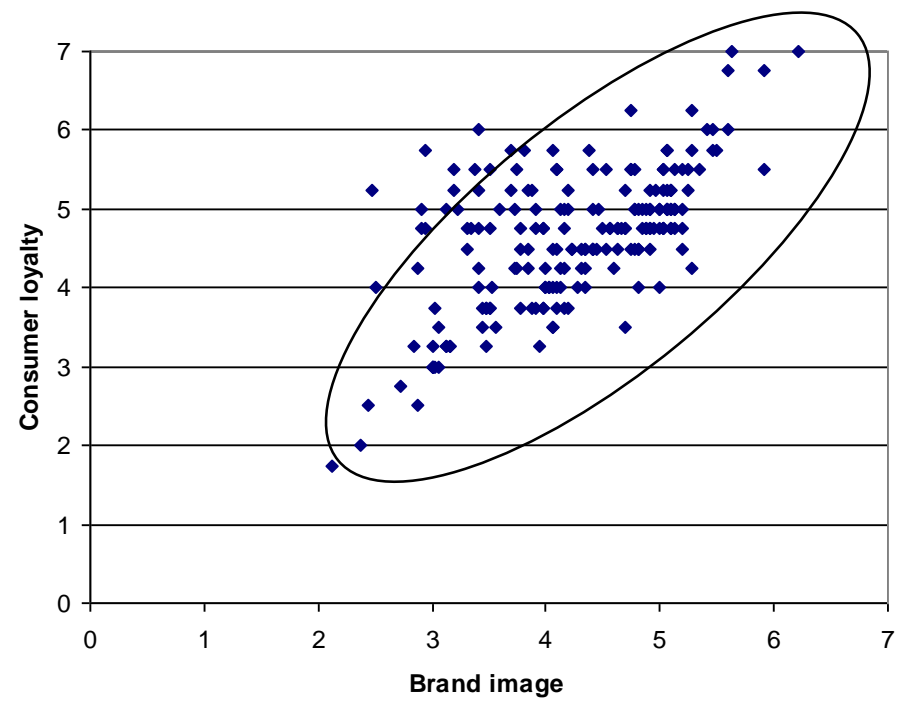

Figure 1. Dispersion diagram brand image-loyalty obtained in the empirical study. Source: author's own study.

Figure 1 presents the points (pairs of coordinates) specifying average values from all 32 variables specifying the brand image and 4 describing motivation loyalty of consumers for all cases. The explicit correlation is observable here. Next, by assuming this graphically presented relation as the basis, with the use of agglomeration method and Ward algorithm, we carried out a cluster analysis for the cases. Diversification in terms of all 36 variables was considered. The obtained tree diagram in presented in Figure 2. 


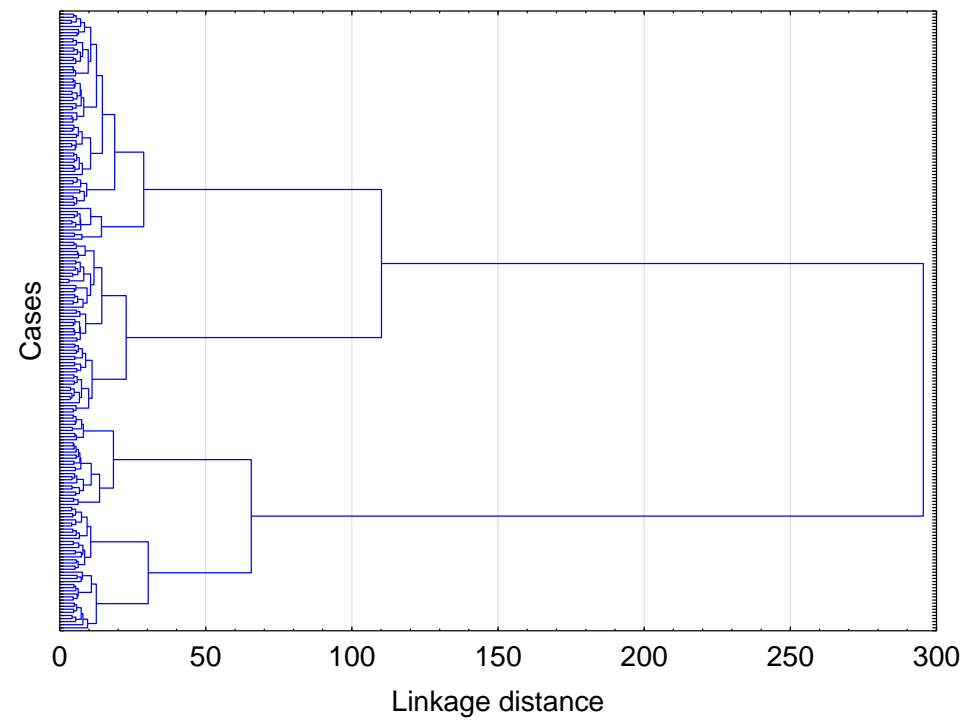

Figure 2. Tree diagram obtained in the empirical study. Source: author's own study.

The analysis of Figure 2 demonstrates that with relatively small distances of the bond (around 50), 4 clusters of cases are visible, next, for the distance of around 65-110, there are 3 clusters, however, for the distance of the bond around 110, we can observe an explicit increase of it for 2 clusters to the value of almost 300 . Therefore, we can notice that the largest diversification is present in the solution, in which we distinguished 2 clusters. This is why this solution was adopted as the final one, although we may, of course, also consider three cluster solutions (cutting of the diagram at the distance of around 65-110) or four clusters solutions (cutting of the diagram at the distance of around 30-65) as reasonable. Each cluster is composed of 100 of 200 analysed cases.

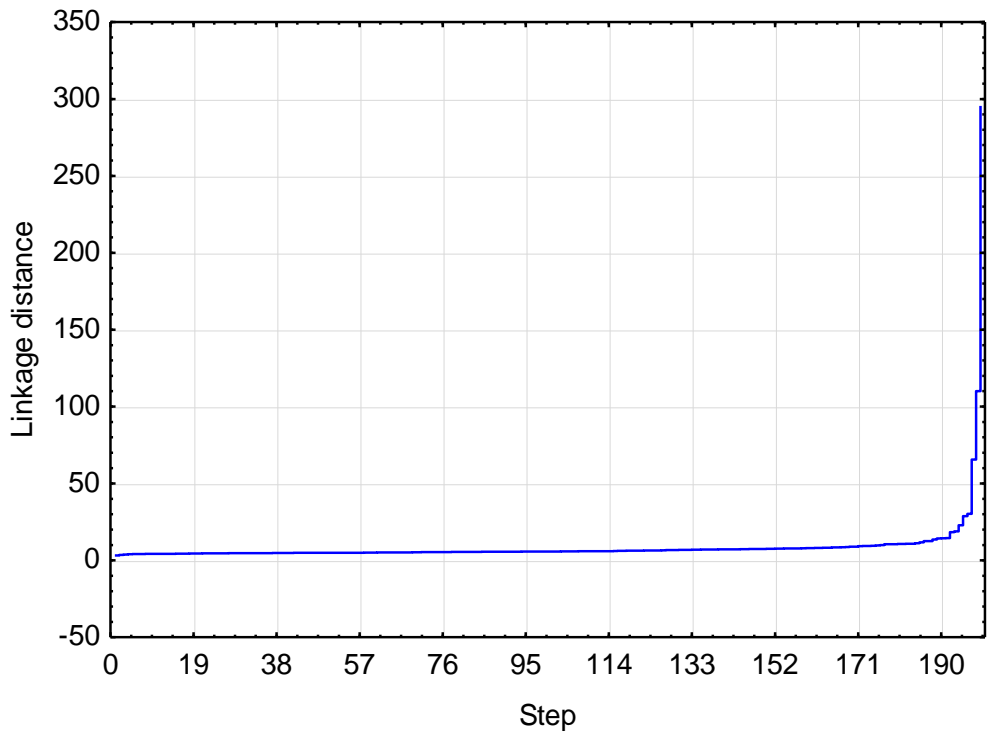

Figure 3. Distance diagram of the bond in relations to the bond phase. Source: author's own study. 
In the next part of this paper, i.e. in Table 3, we present the results of the analysis of variation conducted with the use of the ANOVA test. This shows that for all variables, both the intragroup diversification and inner-group diversification are statistically significant for each variable (for all indicators $p<0,001$ ).

Table 3.

The results of variation analysis - the ANOVA test

\begin{tabular}{|c|c|c|c|c|c|c|}
\hline Variable & Between-group SS & df & Within-group SS & df & $\mathbf{F}$ & p importance \\
\hline W1 & 218,41 & 1 & 225,79 & 198 & 191,52 & 0,000 \\
\hline $\mathrm{W} 2$ & 154,88 & 1 & 166,62 & 198 & 184,05 & 0,000 \\
\hline W3 & 172,98 & 1 & 158,84 & 198 & 215,63 & 0,000 \\
\hline W4 & 146,21 & 1 & 148,19 & 198 & 195,35 & 0,000 \\
\hline W5 & 146,21 & 1 & 156,59 & 198 & 184,87 & 0,000 \\
\hline W6 & 144,50 & 1 & 165,42 & 198 & 172,96 & 0,000 \\
\hline W7 & 117,05 & 1 & 175,71 & 198 & 131,89 & 0,000 \\
\hline W8 & 165,62 & 1 & 147,66 & 198 & 222,08 & 0,000 \\
\hline W9 & 103,68 & 1 & 151,60 & 198 & 135,41 & 0,000 \\
\hline W10 & 85,81 & 1 & 150,07 & 198 & 113,21 & 0,000 \\
\hline W11 & 96,61 & 1 & 164,95 & 198 & 115,96 & 0,000 \\
\hline W12 & 112,50 & 1 & 176,92 & 198 & 125,90 & 0,000 \\
\hline W13 & 108,05 & 1 & 157,51 & 198 & 135,82 & 0,000 \\
\hline W14 & 105,13 & 1 & 177,67 & 198 & 117,15 & 0,000 \\
\hline W15 & 87,12 & 1 & 152,40 & 198 & 113,19 & 0,000 \\
\hline W16 & 80,64 & 1 & 147,23 & 198 & 108,45 & 0,000 \\
\hline W17 & 102,25 & 1 & 148,51 & 198 & 136,32 & 0,000 \\
\hline W18 & 79,38 & 1 & 130,94 & 198 & 120,03 & 0,000 \\
\hline W19 & 74,42 & 1 & 157,96 & 198 & 93,28 & 0,000 \\
\hline W20 & 76,88 & 1 & 150,14 & 198 & 101,39 & 0,000 \\
\hline W21 & 91,13 & 1 & 138,67 & 198 & 130,11 & 0,000 \\
\hline W22 & 93,84 & 1 & 146,15 & 198 & 127,14 & 0,000 \\
\hline W23 & 66,13 & 1 & 165,75 & 198 & 78,99 & 0,000 \\
\hline W24 & 66,13 & 1 & 155,27 & 198 & 84,32 & 0,000 \\
\hline W25 & 74,42 & 1 & 157,40 & 198 & 93,62 & 0,000 \\
\hline W26 & 58,32 & 1 & 171,50 & 198 & 67,33 & 0,000 \\
\hline W27 & 39,60 & 1 & 136,15 & 198 & 57,60 & 0,000 \\
\hline W28 & 33,62 & 1 & 181,88 & 198 & 36,60 & 0,000 \\
\hline W29 & 56,18 & 1 & 159,74 & 198 & 69,64 & 0,000 \\
\hline W30 & 48,02 & 1 & 153,96 & 198 & 61,76 & 0,000 \\
\hline W31 & 41,41 & 1 & 149,47 & 198 & 54,85 & 0,000 \\
\hline W32 & 59,41 & 1 & 165,35 & 198 & 71,14 & 0,000 \\
\hline $\mathrm{L} 1_{\text {kogn }}$ & 47,05 & 1 & 213,15 & 198 & 43,70 & 0,000 \\
\hline $\mathrm{L} 2_{\text {afekt }}$ & 36,13 & 1 & 210,07 & 198 & 34,05 & 0,000 \\
\hline $\mathrm{L}_{\text {kon }}$ & 24,50 & 1 & 171,50 & 198 & 28,29 & 0,000 \\
\hline $\mathrm{L} 4_{\text {akt }}$ & 23,12 & 1 & 156,96 & 198 & 29,17 & 0,000 \\
\hline
\end{tabular}

Source: author's own study.

As made noticeable, all indicators of the image and loyalty diversification are important. Hence, in Table 4, as well as in Figure 4 we list the average values of the variables (image and loyalty indicators) for every cluster and in general for the sample. 
Table 4.

Average values of the indicators of the image and loyalty for clusters and in the sample

\begin{tabular}{|c|c|c|c|c|}
\hline \multirow{2}{*}{ Variable } & \multicolumn{4}{|c|}{ Average } \\
\hline & Cluster 1 & Cluster 2 & Difference (S2-S1) & Sample \\
\hline W1 & 2,55 & 4,64 & 2,09 & 3,60 \\
\hline W2 & 3,07 & 4,83 & 1,76 & 3,95 \\
\hline W3 & 3,04 & 4,90 & 1,86 & 3,97 \\
\hline W4 & 3,20 & 4,91 & 1,71 & 4,06 \\
\hline W5 & 3,25 & 4,96 & 1,71 & 4,11 \\
\hline W6 & 3,13 & 4,83 & 1,70 & 3,98 \\
\hline W7 & 3,27 & 4,80 & 1,53 & 4,04 \\
\hline W8 & 3,03 & 4,85 & 1,82 & 3,94 \\
\hline W9 & 3,34 & 4,78 & 1,44 & 4,06 \\
\hline W10 & 3,62 & 4,93 & 1,31 & 4,28 \\
\hline W11 & 3,47 & 4,86 & 1,39 & 4,17 \\
\hline W12 & 3,52 & 5,02 & 1,50 & 4,27 \\
\hline W13 & 3,43 & 4,90 & 1,47 & 4,17 \\
\hline W14 & 3,38 & 4,83 & 1,45 & 4,11 \\
\hline W15 & 3,52 & 4,84 & 1,32 & 4,18 \\
\hline W16 & 3,44 & 4,71 & 1,27 & 4,08 \\
\hline W17 & 3,32 & 4,75 & 1,43 & 4,04 \\
\hline W18 & 3,65 & 4,91 & 1,26 & 4,28 \\
\hline W19 & 3,80 & 5,02 & 1,22 & 4,41 \\
\hline W20 & 3,81 & 5,05 & 1,24 & 4,43 \\
\hline W21 & 3,72 & 5,07 & 1,35 & 4,40 \\
\hline W22 & 3,57 & 4,94 & 1,37 & 4,26 \\
\hline W23 & 3,70 & 4,85 & 1,15 & 4,28 \\
\hline W24 & 3,87 & 5,02 & 1,15 & 4,45 \\
\hline W25 & 3,86 & 5,08 & 1,22 & 4,47 \\
\hline W26 & 3,99 & 5,07 & 1,08 & 4,53 \\
\hline W27 & 4,09 & 4,98 & 0,89 & 4,54 \\
\hline W28 & 3,94 & 4,76 & 0,82 & 4,35 \\
\hline W29 & 3,95 & 5,01 & 1,06 & 4,48 \\
\hline W30 & 4,00 & 4,98 & 0,98 & 4,49 \\
\hline W31 & 4,17 & 5,08 & 0,91 & 4,63 \\
\hline W32 & 4,17 & 5,26 & 1,09 & 4,72 \\
\hline $\mathrm{L} 1_{\text {kogn }}$ & 3,92 & 4,89 & 0,97 & 4,41 \\
\hline $\mathrm{L} 2_{\text {afekt }}$ & 4,17 & 5,02 & 0,85 & 4,60 \\
\hline $\mathrm{L}_{\text {kon }}$ & 4,35 & 5,05 & 0,70 & 4,70 \\
\hline $\mathrm{L} 4_{\mathrm{akt}}$ & 4,52 & 5,20 & 0,68 & 4,86 \\
\hline
\end{tabular}

Source: author's own study. 


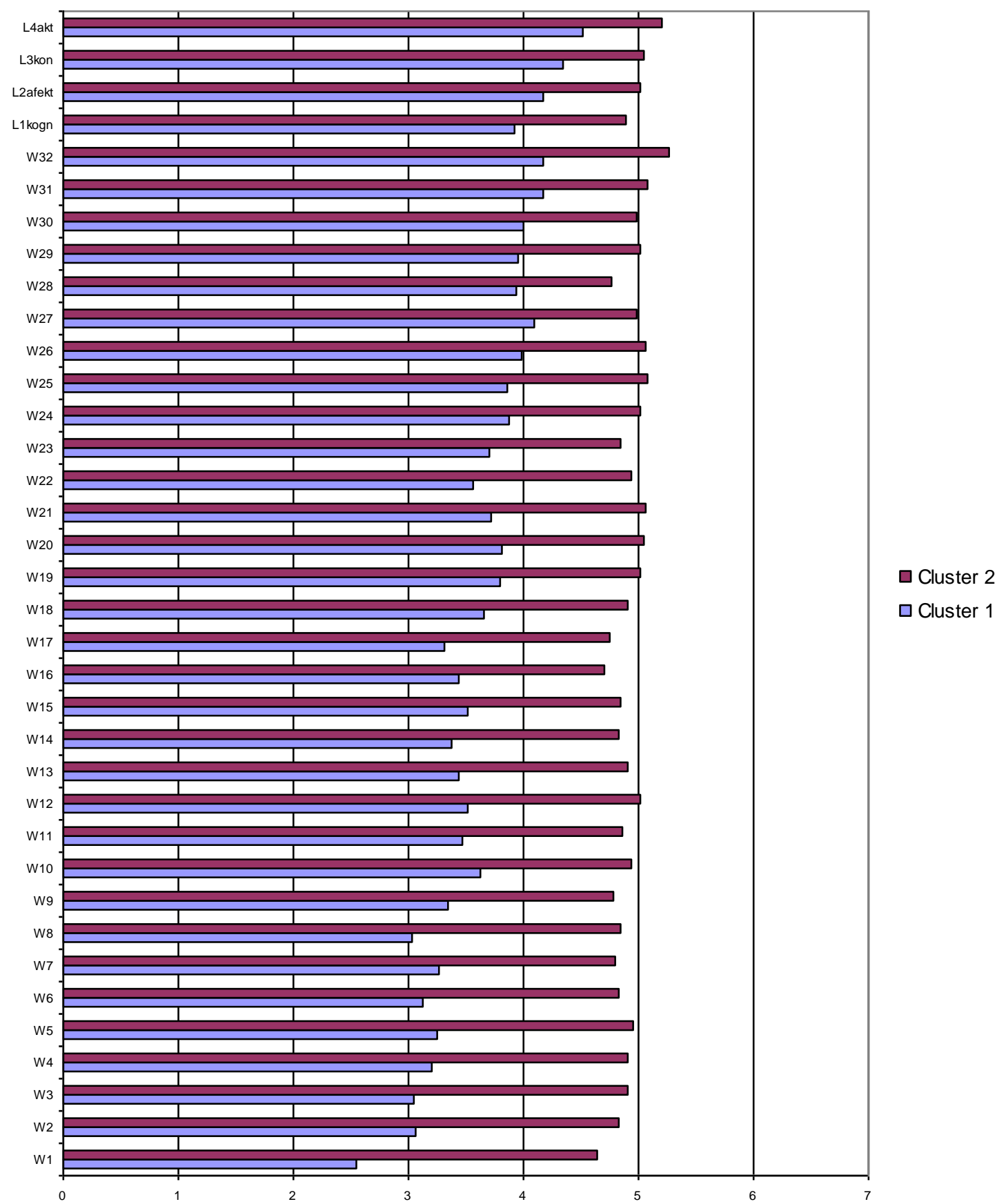

Figure 4. Average values of image and loyalty indicators for the clusters. Source: author's own study.

On the basis of the analysis of average values of variables included in Table 4 and Figure 4, we verified the hypotheses posed in the introduction to this paper.

In particular, when verifying the $\mathrm{H}_{1}$ hypothesis it was notable that for all jointly analysed indicators of perceiving the image and indicators of the loyalty of the consumers, diversification is very important, therefore, a relation exists between the brand image and motivation loyalty of the consumers. The said relation has a positive character, meaning that better perception of the brand image is connected with a higher level of motivation loyalty of the consumers. 
In contrast, when verifying $\mathrm{H}_{2}$ hypothesis, it was evident that the consumers in the analysed market belong to two separate clusters in terms of the perception of the brand image and loyalty towards it. An explicit polarization of the identified groups in terms of the values of analysed variables is observed. The first cluster consists of "malcontents", i.e. consumers with poor perception of the brand image, and, at the same time, consumers who declare a low level of motivation loyalty. The second cluster covers the 'enthusiasts', i.e. persons who evaluate highly both the brand image and the level of their loyalty to the marque. In the sample these clusters are the same in terms of the number - they group 100 cases each. In this way we verified both working hypotheses.

\section{Conclusions}

The purpose of this paper was to identify the relations of the brand image of a passenger car with the loyalty of the consumers and to demonstrate the segmentation of the consumers. In consequence of the carried out cluster analysis, we uncovered the following:

- By verifying the $\mathrm{H}_{1}$ hypothesis we showed that the diversification of all studied indicators is important, therefore, there is a relation between the brand image and motivation loyalty of the consumers. This relation has positive character.

- By verifying $\mathrm{H}_{2}$ hypothesis, we revealed that the consumers in the analysed market belong to two diverse clusters with an explicit polarization in terms of the evaluation of the brand image and loyalty towards it. The first one groups together the "malcontents', i.e. the consumers with poor perception of both the brand image and who hold a low level of motivation loyalty. The second cluster includes "the enthusiasts", i.e. the persons who evaluate both the brand image and the level of their own loyalty at a very high level.

As a recommendation for the practice of management and marketing, we must underline that car manufacturers need to put intensive work into the shaping of the identity and brand image. This should contribute to increased brand loyalty among consumers.

It should be added that as in every kind of a research, we must be aware of the limitations of the obtained results and of the assumptions. In this study, the limitation mainly concerns, above all, the low number of cases included in the sample. The increase of its number or the methods of the selection of respondents could render the creation of a better model impossible. It should be also mentioned that the analysis of clusters is not a statistical test and thus the interpretation of its results is burdened with discretion. Therefore, it is hard to compare the competitive taxonomic established with the use of this particular method. Moreover, an obvious weakness exists in the motivation loyalty and its lip service in respect of the factuality of the behavioural loyalty. Thus the widening of the scope of the measurement with the indicators of this kind of loyalty (which was omitted in this paper), may be considered. 


\section{References}

1. Allen, D., and Rao, T. (2000). Analysis of Customer Satisfaction Data. Milwaukee: ASQ Quality Press.

2. Anisimova, T. (2007). The effects of corporate brand attributes on attitudinal and behavioural consumer loyalty. Journal of Consumer Marketing, 24(7), 395-405. doi: 10.1108/07363760710834816.

3. Banahene, S., Ahudey, E., and Asamoah, A. (2017). Analysis of SERVQUAL Application to Service Quality Measurement and Its Impact on Loyalty in Ghanaian Private Universities. Journal of Management and Strategy, 8(4), 18-33. doi: 10.5430/jms.v8n4p18.

4. Chaudhuri, A. and Holbrook, M. (2001). The Chain of Effects from Brand Trust and Brand Affect to Brand Performance: The Role of Brand Loyalty. Journal of Marketing, 65(2), 81-93, doi: 10.1509/jmkg.65.2.81.18255.

5. Chi, H. et al. (2009). The Impact of Brand Awareness on Consumer Purchase Intention: The Mediating Effect of Perceived Quality and Brand Loyalty. The Journal of International Management Studies, 4(1), 135-144.

6. Consumer Reports (2012). Consumers See Fewer Differences Among Car Brands, http://consumerreports.org , 21.12.2018.

7. Dębski, M. (2009). Kreowanie silnej marki. Warszawa: PWE.

8. Delgado-Ballester, E., and Munuera-Aleman, J. (2001). Brand trust in the context of consumer loyalty. European Journal of Marketing, 35(11/12), 1238-1258. doi: 10.1108/EUM0000000006475.

9. Dick, A., and Basu, K. (1994). Consumer Loyalty: Toward an Integrated Conceptual Framework. Journal of the Academy of Marketing Science, Spring, 99-113.

10. Du, Y., and Tang, Y. (2014). A Literature Review on the Relationship Between Service Quality and Consumer Loyalty. Business and Management Research, 3(3), 27-33. doi: 10.5430/bmr.v3n3p27.

11. Eakuru, N., and Mat, N. (2008). The application of structural equation modeling (SEM) in determining the antecedents of consumer loyalty in banks in South Thailand. The Business Review, 10(2), 129-139.

12. Fornell, C. (1992). A national consumer satisfaction barometer: the Swedish experience. Journal of Marketing, 56, 6-12. doi: 10.2307/1252129.

13. Gabor, M. (2016). Romanian Young Consumers Perception of Car Brands: A Personal Construct Theory Approach. Eurasian Journal of Business and Economics, 18(9), 17-39. doi: 10.17015/ejbe.2016.018.02.

14. Gremler, D., and Brown, S. (1996). Service loyalty: its nature, importance, and implications. In: B. Edwardson, B. et al. (eds.), Advancing Service Quality: A Global Perspective. International Service Quality Association. 
15. Grzegorczyk, A. (2005). Wizerunek marki jako narzędzie oddziaływania rynkowego. In: A. Grzegorczyk (ed.), Instrumenty kształtowania wizerunku marki. Warszawa: Wyższa Szkoła Promocji.

16. Herbig, P., and Milewicz, J. (1995). The relationship of reputation and credibility to brand success. Journal of Consumer Marketing, 12(4), 18-24. doi: 10.1108/EUM0000000002601.

17. Hibbert, S., Hogg, G., and Quin, T. (2005). Social entrepreneurship: Understanding consumer motives for buying The Big Issue. Journal of Consumer Behaviour, 5(3), 29-40. doi: 10.1002/cb.6.

18. Jalilvand, M., and Samiei, N. (2012). The effect of electronic word of mouth on brand image and purchase intention: An empirical study in the automobile industry in Iran. Marketing Intelligence \& Planning, 30(4), 460-476. doi: 10.1108/02634501211231946.

19. Kall, J. (2002). 13 zasad zarządzania marką. Marketing w Praktyce, 2, 4-8.

20. Kall, J. (2006). Istota marki. Integracja Europejska, 3, 60-64.

21. Kall, J., Kłeczek, R., and Sagan, A. (2013). Zarządzanie marka. Warszawa: Wolters Kluwer.

22. Kotler, Ph. (2006). The new marketing and sales-strategies and tactics. XIX Seminar of the Series Authorities.

23. Kotler, Ph., and Armstrong, G. (1989). Principles of Marketing. London: Prentice Hall International.

24. Kressmann, F. et al. (2006). Direct and indirect effects of self-image congruence on brand loyalty. Journal of Business Research, 59(9), 955-964. doi: 10.1016/j.jbusres.2006.06.001.

25. Kwiatkowska, A. (2013). Utrzymanie lojalności konsumenckiej w sytuacjach kryzysowych. In: A. Wiśniewska (ed.), Kształtowanie lojalności konsumenckiej. Warszawa: WSP.

26. Lam, R., and Burton, S. (2006). SME banking loyalty (and disloyalty): A qualitative study in Hong Kong. International Journal of Bank Marketing, 24(1), 37-52. doi: 10.1108/ 02652320610642335 .

27. Lau, G., and Lee, S. (1999). Consumers' Trust in a Brand and the Link to Brand Loyalty. Journal of Market-Focused Management, 4(4), 341-370.

28. Liczmańska, K. (2008). Silna marka jako źródło przewagi konkurencyjnej w momencie zakupu. Roczniki Ekonomiczne Kujawsko-Pomorskiej Szkoły Wyższej w Bydgoszczy, 1, 87-99.

29. Lotko, A. (2018). Jakość ustug bankowości internetowej a lojalność klientów indywidualnych. Radom: Wydawnictwo Instytutu Technologii Eksploatacji.

30. Lotko, M., Lotko, A., and Korneta, P. (2018). Ocena jakości usług obstugi technicznej i naprawy samochodów osobowych. Radom: Instytut Naukowo-Wydawniczy Spatium.

31. Małysa-Kaleta, A. (2016). Misja konsumenta we współczesnym świecie. Handel Wewnętrzny, 4(363), 142-152.

32. Morchett, D., Swoboda, B., and Foscht, T. (2005). Perception of store attributes and overall attitude towards grocery retailers: The role of shopping motives. International Review of 
Retail, Distribution \& Consumer Research, 15(4), 423-447. doi: 10.1080/ 09593960500197552.

33. NRC (2014). Auto Brand Perceptions. Consumer Reports National Research Center.

34. Nyadzayo, M., and Khajehzadeh, S. (2016). The antecedents of consumer loyalty: A moderated mediation model of consumer relationship management quality and brand image. Journal of Retailing and Consumer Services, 30, 262-270. doi: 10.1016/ j.jretconser.2016.02.002.

35. Oliver, R. (1999). Whence consumer loyalty? Journal of Marketing, 63, 33-44.

36. Reichheld, F., and Sasser, W. (1990). Zero Defections: Quality Comes to Service. Harvard Business Review, 68(5).

37. Reichheld, F., and Schefter, P. (2000). E-loyalty: Your secret weapon on the web. Harvard Business Review, 78, 105-113.

38. Remer, D. (2004). Kształtowanie wizerunku marki na przykładzie samochodów osobowych Volvo. Unpublished dissertation. Katowice: Górnośląska Wyższa Szkoła Handlowa.

39. Robinson, T., and Gammon, S. (2004). A question of primary and secondary motives: revisiting and applying the sport tourism framework. Journal of Sport Tourism, 9(3), 221-233. doi: 10.1080/1477508042000320223.

40. Selnes, F. (1993). An Examination of the Effect of Product Performance on Brand Reputation, Satisfaction and Loyalty. European Journal of Marketing, 27(9), 19-35. doi: 10.1108/03090569310043179.

41. Siemieniako, D., and Urban, W. (2018). Lojalność klientów: Modele, motywacja i pomiar. Warszawa: PWN.

42. StatSoft (1997). STATISTICA PL. Tom III: Statystyki II. Kraków: StatSoft.

43. Stevens, J. (2009). Applied Multivariate Statistics for the Social Science. New York: Routledge.

44. Studzińska, E. (2015). Lojalność klienta-pojęcie, podział, rodzaje i stopnie. In: T. Borys, P. Rogala, and P. Skowron, (eds.), Zrównoważony rozwój organizacji - odpowiedzialne zarzadzanie. Wrocław: Wydawnictwo Uniwersytetu Ekonomicznego.

45. Sulikowski, P. and Ździebko, T. (2015). Uwarunkowania lojalności, retencji i churnu klientów na przykładzie branży telekomunikacyjnej. Handel Wewnętrzny, 3, 273-284.

46. Sułkowski, Ł. (2015). Epistemologia i metodologia zarządzania. Warszawa: PWE.

47. TNS OBOP (2011). Jak postrzegamy marki samochodowe. Warszawa, TNS OBOP.

48. Tryon, R. (1939). Cluster Analysis. New York: McGraw-Hill.

49. Wiedmann, P. et al. (2014). Drivers and Outcomes of Brand Heritage: Consumers' Perception of Heritage Brands in the Automotive Industry. Journal of Marketing Theory and Practice, 19(2), 205-220. doi: 10.2753/MTP1069-6679190206.

50. Woźniakowski, M. (2018). Kształtowanie wizerunku marki na rynku motoryzacyjnym wśród dzieci. Handel Wewnętrzny, 3(374), 415-423. 